American Journal of Environmental Sciences 8 (1): 11-15, 2012

ISSN 1553-345X

(C) 2012 Science Publications

\title{
Historical Changes in Polychlorinated Biphenyls Contaminated Sediments
}

\author{
${ }^{1}$ Viet D. Dang, ${ }^{2}$ David M. Walters and ${ }^{1}$ Cindy M. Lee \\ ${ }^{1}$ Department of Environmental Engineering and Earth, \\ Sciences, Clemson University, \\ 342 Computer Court, SC, 29625, Anderson \\ ${ }^{2}$ U.S Environmental Protection Agency, \\ National Research Exposure Laboratory, \\ 26 W. Martin Luther King Drive, OH, 45268, Cincinnati
}

\begin{abstract}
Problem statement: PCBs contamination continues to pose a health risk to aquatic environments due to their recalcitrance and bioaccumulation. The Sangamo Weston/Twelvemile Creek/Lake Hartwell Superfund Site is an example of such a health risk as a result of PCBs discharged from a former capacitor manufacturing plant. We conducted a study in twelvemile creek (Clemson, SC, USA) to examine the temporal trend of PCB contaminated sediments. Approach: Surface sediments were sampled at four sites in fall 2008 to compare with concentrations measured in past studies. Total PCBs and congener-specific analyses were performed on Gas Chromatography-Electron Capture Detector (GC-ECD). Results: Total PCB concentrations ranged from 0.026-0.18 $\mu \mathrm{g} \mathrm{g} \mathrm{g}^{-1}$, which were one order of magnitude lower than levels measured in $1987\left(<0.20-10.23 \mu \mathrm{g} \mathrm{g}^{-1}\right)$. Total PCBs in this study (based on more than 130 congeners) were similar to those observed in 2003-2004 (based on only 20 congeners). PCB congener patterns indicated that PCBs near the source were dominated by lower chlorinated congeners while heavy congeners were persistent further downstream. Conclusion: Physical and biochemical processes such as natural attenuation, mixing/dispersion and PCBs degradation are contributing to the decreasing concentrations after the discharge was eliminated in 1975. The congener pattern shift is likely attributed to a loss via volatilization and export of contaminated sediment from the stream. Burial could be a potential means to prevent resuspension into the water column.
\end{abstract}

Key words: Polychlorinated Biphenyls (PCBs), natural attenuation, Accelerated Solvent Extraction system (ASE), Fine Benthic Organic Matter (FBOM), Electron Capture Detector (ECD), National Priorities List (NPL), Food and Drug Administration (FDA)

\section{INTRODUCTION}

Synthetic Chlorinated Hydrocarbons (e.g., PCBs, DDTs and HCHs) are widely distributed throughout the aquatic environment. Polychlorinated Biphenyls (PCBs) are some of the most persistent and ubiquitous pollutants in the environment. Their physicochemical properties are variable owing to different number of chlorines attached to the biphenyl molecule. The functional properties that make PCBs ideal for "open" applications (e.g., heat insulators, transformers and dielectric fluids) result from the fact those commercialgrade PCBs are mixtures or Aroclors (Baker, 1980). Because of their potential carcinogenicity, since the late 1970s the commercial products have not been manufactured on a large scale (Harrad et al., 1994). However, environmental cycling has led to worldwide distribution of PCBs. Measurable levels of PCBs have been documented universally in ambient air, soils, rivers, sediments and tissues of organisms (EPA, 1976). Once released into the environment, PCBs initially tend to adsorb to organic matter in sediment, bioaccumulate in fatty tissues and subsequently transfer via diet to higher organisms in the food web. Additionally, sediments control concentrations and distributions of PCBs in the water column through resuspension in the short term while burial is the ultimate fate of PCBs in the long term (Ko and Baker, 1995; Jonsson and

Corresponding Author: Cindy M. Lee, Department of Environmental Engineering and Earth Sciences, Clemson University, 342 Computer Court, Anderson, SC, 29625 Tel: 864-656-1006 Fax: 864-656-0672 
Carman, 2000). If sediment accumulation/burial rates are faster than the rate at which PCBs can desorb, then adsorption essentially becomes a dominant process and sediments become a sink for PCB contamination within the system (Mackay, 1983). Otherwise, disruption of the sediment profile (through storms, dredging,) increases PCBs desorption from previously buried sediments and thus potentially increases water concentrations.

The Sangamo-Weston/Twelvemile Creek/Lake Hartwell Superfund site located in Pickens, South Carolina, USA, was contaminated with PCBs-containing wastes released from a former capacitor manufacturing plant. Approximately 181 metric tons of PCBs were discharged with effluent directly into Town Creek, a tributary of Twelvemile Creek, which is in turn a major tributary of Lake Hartwell (EPA, 1990). The Lake Hartwell reservoir was constructed between 1955 and 1963 by the U.S Army Corps of Engineers. The Sangamo site was proposed for the National Priorities List (NPL) in January 1987 and was finalized on the NPL in February 1990 (EPA, 1990). EPA and South Carolina Department of Health and Environmental Control (SCDHEC) have completed several studies to assess PCB contamination in the Lake Hartwell and Twelvemile Creek ecosystem. Results indicated that concentrations in fish species in Lake Hartwell often exceeded the U.S. Food and Drug Administration (FDA) safe tolerance limit of $2 \mathrm{mg} \mathrm{kg}^{-1}$ (EPA, 1990). Accumulations were detected in the sediments as far downstream as the Lake Hartwell dam $(91 \mathrm{~km}$ from the source), while minor levels of PCB contamination persisted in Town Creek near the Sangamo Weston plant site (EPA, 1990; Baker, 1994). The vertical trend of PCBs contaminated sediments in the lake has also been evaluated (Brenner et al., 2004; Sivey and Lee, 2007). In general, concentrations in the lake systems were relatively low at the sediment-water interface and then increased with depth until the maximum PCB concentration was measured at $35-40 \mathrm{~cm}$. However, a temporal distribution of PCBs accumulated in Twelvemile Creek sediments has not been published because the system is more dynamic with more frequent disturbance and greater downstream transport than the lake system. In addition, knowledge of the historical profile of the surface zone is important to adequately characterize the horizontal contamination and to determine the quality of recently deposited sediment. Therefore, this study aimed to provide insight into the distribution and magnitude of PCB contamination in Twelvemile Creek sediments via assessment of a historical profile. We hypothesized that PCB concentrations at the water/sediment interface in Twelvemile Creek were decreasing because of continual import of clean sediments from upstream, mixing/dispersion facilitated by further downstream export and aerobic degradation.

\section{MATERIALS AND METHODS}

Sampling methods: The study was conducted in Town Creek, where the Sangamo-Weston (S-W) plant was located and extended to the Twelvemile Creek system (Fig. 1). We sampled surface sediments at four locations in fall 2008. Briefly, a large stainless steel spoon was used to collect the surface sediments from shallow and depositional habitats in the stream. The depth of sediments sampled ranged from $3-5 \mathrm{~cm}$ depending on the composition of the sediment substrate. Collection sites were located from 2-25 km downstream of the plant site. Three replicates were collected at each sampling site. Samples were stored in solvent-cleaned amber glass containers, placed in a cooler with ice for transport to the laboratory and frozen at $-200 \mathrm{C}$ until analysis. While sample collection in a 2003-04 study was similar to our current study, core samples were collected and dissected into the top, middle and bottom sections in the 1987 study.

Extraction and analytical methods: Sediment extractions were conducted with a Dionex Accelerated Solvent Extraction system (ASE-200) using methylene chloride EPAUS, 2005. Sample clean-up was accomplished via sulfuric acid and alumina column. Extracts were solvent exchanged with isooctane prior to GC analysis. Total PCBs and congener-specific PCBs were analyzed with an Agilent 6890-GC equiped with a RTX-5 column (Restek, Bellefonte, PA; $60 \mathrm{~m}$ length, $0.25 \mathrm{~mm}$ diameter and $0.25 \mu \mathrm{m}$ film thickness) and a 63Ni Electron Capture Detector (ECD). The GC conditions and analytical quantification were described elsewhere (Dang, 2007; Dang et al., 2010). Surrogate standards containing PCBs 14 and 169 were added to the samples prior to extraction. Recovery factors of $80.73 \pm 9.13 \%$ and $85.14 \pm 13.11 \%$ were attained for PCBs 14 and 169 , respectively. PCB concentrations were not corrected for recovery. Quantitative analysis was based on internal standards using Aldrin and PCB 209. Our method was equivalent to the method used in the 2003-04 study (Walters et al., 2008); while a sonication method was adapted for the 1987 study (Germann, 1988).

In addition, total PCB concentrations were based on 65,20 and 130 congeners for 1987, 2003-04 and our study, respectively. 


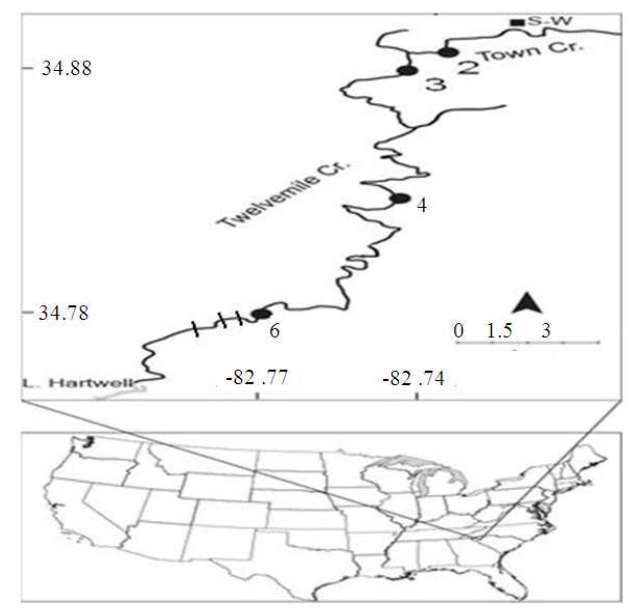

Fig. 1: Map of the study area showing the SangamoWeston plant (SW) and four collection sites: 2, 3, 4 and 6 . Transverse lines downstream of site 6 represent low-head dams considered for removal under ongoing mitigation efforts. Source: Dang et al., 2010

\section{RESULTS AND DISCUSSION}

Total PCB concentrations in sediments were highly variable ranging from $0.026-0.18 \mu \mathrm{g} \mathrm{g}^{-1}$ (Table 1). The magnitude of PCBs contamination was about one order of magnitude lower than the 1994 Record of Decision cleanup requirement goal, which was proposed at $1 \mu \mathrm{g}$ $\mathrm{g}^{-1}$ (EPA, 1990). Total PCBs in Twelvemile Creek surface sediments (top section ranging from $0-5 \mathrm{~cm}$ ) in the 1987 study measured by Germann (1988) were from $<0.22-10.23 \mu \mathrm{g} \mathrm{g}^{-1}$. Note that the number of congeners included in the 2008 total were twice the 1987 total, clearly indicating a large decrease over the time span. In addition, total PCBs decreased at the sediment-water interface in the Lake Hartwell by about one order of magnitude between 1987 and 2004 (Sivey and Lee, 2007). Because Town Creek was confirmed as the only tributary contributing $\mathrm{PCBs}$ to Twelvemile Creek (EPA, 1990), decreasing PCB concentrations would reflect a decline in PCB input to the system, the burial and/or dilution of previously contaminated sediment by mixing with clean sediment and PCB dechlorination. PCBs in historical surficial sediments were found to be highest near the plants discharge point on Town Creek and generally decreasing with increasing distance downstream from the plant site (EPA, 1990). Similarly, our current studies measured a lower level of PCBs at site 6 (25 km from the source) than site 2 ( $2 \mathrm{~km}$ from the source) except for site 4 (Fig. 2). This variation is due to the fact that sediment in the system is primarily comprised of sand and gravel with low Total Organic Carbon content (TOC) ranging from 0.1-3.6\% (EPA, 1990). According to Walters et al. (2008), TOC normalized PCB concentrations in sediment and Fine Benthic Organic Matter (FBOM), deposited organic matter between 48 and $250 \mu \mathrm{m}$ mesh size, had similar patterns. FBOM has a higher affinity for sorption of hydrophobic contaminants like PCBs than inorganic sediments and can serve as a potential surrogate for sediment in determining trace levels of persistent organic pollutants.

Although PCB concentrations did not appear to be noticeably different at all four sites between this study and the 2003-04 study conducted by Walters et al. (2008) (Fig. 2), more than six times the congeners were included in the 2008 total as for the 2003-04 total. It is likely that the PCBs continued to decrease over the four years. However, PCBs in fish have not responded measurably to the decreased surface sediment trends. PCB concentrations in yellowfin shiner (Notropis lutipinnis) collected from 2003-2005 in Twelvemile Creek continue to be above the $2.0 \mathrm{mg} \mathrm{kg}^{-1}$ FDA limit (Walters et al., 2008; Dang, 2007). In order to achieve stream restoration, the Natural Resource Trustees (NRTs) and Schlumberger (current responsible party) proposed to remove two Twelvemile Creek impoundments (and possibly a third) located along the lower portion of Twelvemile Creek DNR, 2006. These impoundments are associated with Woodside II, Woodside I and the Easley-Central dams situated 2.4, 4.0 and $5.1 \mathrm{~km}$ upstream of the Lake Hartwell backwater, respectively (Fig. 1). The removal will encourage greater sediment transport downstream to contaminated portions of Lake Hartwell. The process to remove the first impoundment (Woodside I) is currently underway.

Analysis of congener distribution patterns (Fig. 3) indicated greater accumulations of lower chlorinated congeners (di-+tri and tetraCBs) at upstream sites (site 2) and greater accumulation of higher chlorinated congeners (hexa-, hepta- + octaCBs) at downstream sites (site 6). While penta and hexaCBs accounted for > $50 \%$ of total PCBs, nona- and decaCBs were comprised $<0.05 \%$ of total PCBs at all sites and excluded from the analysis. Walters et al. (2008) also showed a similar downstream shift to higher chlorinated congeners across the Twelvemile Creek food web.

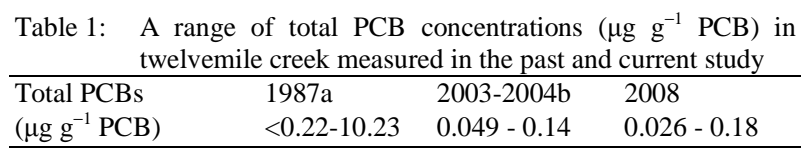




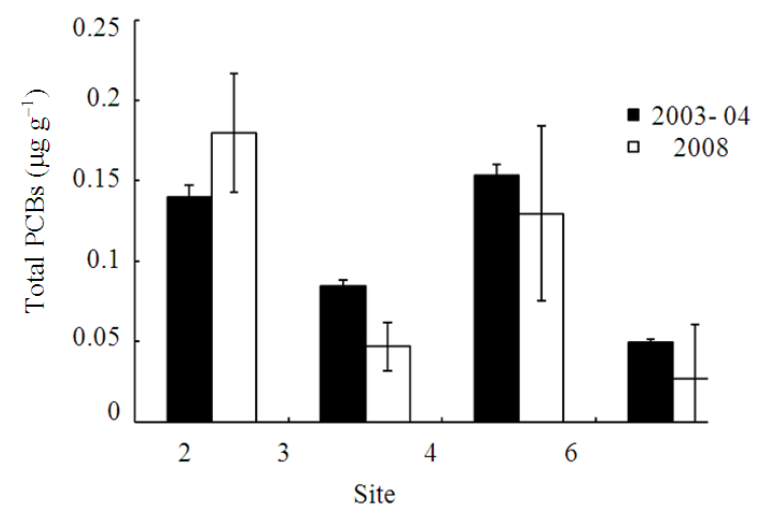

Fig. 2: Total PCB concentrations (mean $\pm 1 \mathrm{SD}, \mu \mathrm{g} \mathrm{g}^{-1}$ PCBs) between the 2003-04 (Walters et al., 2008) and current study

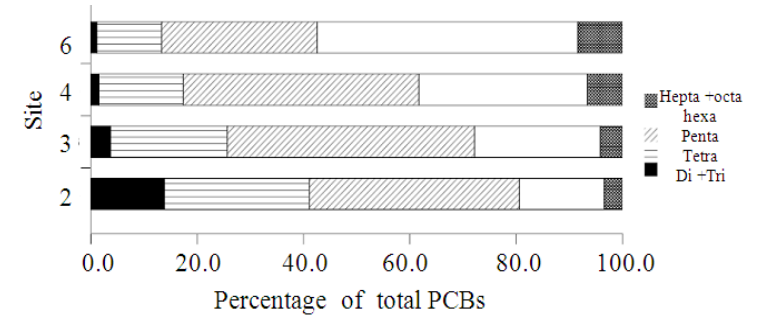

Fig. 3: Proportion (of $\Sigma$ PCBs) of homologues measured at four sites. Nona- and deca-CBs comprised $<0.05 \%$ of total PCBs in any sample and were exclude

Light congeners (e.g., di, tri-chlorinated biphenyls) could be subject to aerobic biodegradation compared to the heavy congeners, which are more persistent and less biodegradable under aerobic conditions typically occurring in the stream surface sediments.

PCBs with up to four chlorine atoms have been reported susceptible to aerobic degradation in laboratory investigations (Abraham et al., 2002; Master et al., 2002). In addition, during sediment resuspension and transport events, the preferential sorption of higher chlorinated congeners and the loss of lower chlorinated congeners via volatilization could explain the congener distribution shift (Baker, 1994). Dunnivant et al. (1988) proposed this process as the dominant PCB weathering mechanisms in the system.

\section{CONCLUSION}

This study reviews the magnitude and distribution of PCB contamination in the sediment of the Twelvemile Creek Superfund Site. Our evidence shows that 20 years were required to decrease the concentrations by an order of magnitude. We also attribute that natural attenuation and mixing/dispersion of sediments are playing major roles in diminishing PCB concentrations in surface sediments. Much of the contaminated sediments were exported from the system and deposited in the Twelvemile Creek Arm of Lake Hartwell since the termination of the discharge. However, resuspension into the water column of the remaining sediments is likely occurring and contributing to the high PCB levels measured in fish species.

\section{REFERENCES}

Abraham, W.R., B. Nogales, P.N. Golyshin, D.H. Pieper and K.N. Timmins, 2002. Polychlorinated biphenyl-degrading microbial communities in soils and sediments. Curr. Opin. Microbiol., 5: 246-253. DOI: $10.1016 / \mathrm{S} 1369-5274(02) 00323-5$

Baker, L.A. 1994. Environmental chemistry of lakes and reservoirs. 1st Edn., American Chemical Society, ISB:N 0841225265 pp: 627.

Baker, R.A., 1980. Contaminants and Sediments: Analysis, Chemistry, Biology. 1st Edn., Ann Arbor Science, Ann Arbor, Michigan. ISBN: 0250403072 pp: 627.

Brenner, R.C., V.S. Magar, J.A. Ickes, E.A. Foote and J.E. Abbottc et al., 2004. Long-term recovery of PCB-contaminated surface sediments at the Sangamo-Weston/Twelvemile Creek/Lake Hartwell Superfund Site. Environ. Sci. Technol., 38: 2328-2337. DOI: 10.1021/es030650d

Dang, V.D., 2007. Achiral and chiral analysis of Polychlorinated Biphenyls (PCBs) in the aquatic and riparian food webs in Twelvemile Creek, South Carolina. M.S. Thesis, Clemson University, Clemson, SC.

Dang, V.D., D.M. Walters and C.M. Lee, 2010. Transformation of chiral Polychlorinated Biphenyls (PCBs) in a stream food web. Environ. Sci. Technol., 44: 2836-2841. DOI: 10.1021/es902227a

Dunnivant, F.M., J.T. Coates and A.W. Elzerman, 1988. Experimentally determined Henry's law constants for 17 polychlorobiphenyl congeners. Environ. Sci. Technol., 22: 448-453. DOI: 10.1021/es00169a013

EPA, 1976. PCBs in the United States Industrial Use and Environmental Distribution. 1st Edn., Environmental Protection Agency, Washington, pp: 334.

EPA, 1990. Superfund record of decision: Sangamo/Twelve-Mile/Hartwell PCB, SC : first remedial action. 1st Edn., Environmental Protection Agency, USA., pp: 247. 
Germann, G.G., 1988. The distribution and mass loading of polychlorinated biphenyls in Lake Hartwell sediments. 1st Ed., M.S. Thesis, Clemson University, Clemson, SC, pp: 314.

Harrad, S.J., A.P. Stewart, R. Alcock, R. Boumphrey and V. Burnett et al., 1994. Polychlorinated biphenyls (PCBs) in the British environment: Sinks, sources and temporal trends. Environ. Pollut., 85: 131-146. DOI: 10.1016/02697491(94)90079-5

Jonsson, A. and R. Carman, 2000. Distribution of PCBs in Sediment from Different Bottom Types and Water Depths in Stockholm Archipelago, Baltic Sea. Ambio., 29: 277-281. DOI: 10.1579/00447447-29.4.277

Ko, F.C. and J.E. Baker, 1995. Partitioning of hydrophobic organic contaminants to resuspended sediments and plankton in the mesohaline Chesapeake Bay. Mar. Chem., 49: 171-188. DOI: 10.1016/0304-4203(94)00064-K

Mackay, D., S. Paterson., S.J. Eisenreich and M.S. Simmons, 1983. Physical Behavior of PCBs in the Great Lakes. 1st Edn., Ann Arbor Science, Ann Arbor, Michigan, ISBN: 0250405849 pp: 442.
Master, E.R., V.W.M. Lai., B. Kuipers., W.R. Cullen and W.W. Mohn, 2002. Sequential Anaerobic-Aerobic Treatment of Soil Contaminated with Weathered Aroclor 1260. Environ. Sci. Technol., 36: 100-103. DOI: 10.1021/es0019301

Sivey, J.D. and C.M. Lee, 2007. Polychlorinated biphenyl contamination trends in Lake Hartwell, South Carolina (USA): Sediment recovery profiles spanning two decades. Chemosphere., 66: 18211828. DOI: 10.1016/j.chemosphere.2006.09.013

Walters, D.M., K.M. Fritz, B.R. Johnson, J.M. Lazorchak and F.H. McCormick, 2008. Influence of Trophic Position and Spatial Location on Polychlorinated Biphenyl (PCB) Bioaccumulation in a Stream Food Web. Environ. Sci. Technol., 42: 2316-2322. DOI: 10.1021/es0715849 